\title{
Facebook Marketing Intelligence
}

\author{
Daan Groothuis \\ Ton AM Spil (Corresponding Author) \\ Robin Effing \\ a.a.m.spil@utwente.nl \\ University of Twente
}

\begin{abstract}
Facebook marketing is becoming an increasingly important tool for companies to influence consumer decision-making. However, there is currently little empirical knowledge about the extent of influence of Facebook marketing on the decision-making process of consumers. This study contributes to these gaps in the literature and investigates the influence of Facebook marketing activities on the decision-making process of consumers. The theory revealed four Facebook marketing activities that affected the first two phases of the decision-making process. These Facebook marketing activities were advertisements, recommend/share, likes and reviews. Whether they actually had an impact has been tested with the help of survey among 112 respondents. The results of the regression analysis showed that all four Facebook marketing activities had a positive influence on the decision-making process.
\end{abstract}

\section{Introduction}

There are millions of individuals on the internet who want to meet other users to gather information and share experiences or information. These millions of individuals are using social media channels like Facebook, Twitter, Snapchat and Instagram. Because a lot of user information becomes available via social media, companies use social media as a marketing tool [9]. This has changed the way companies communicate with their customers and share information about their products [34]. Consumers also use social media to communicate with retailers, with the result that consumer engagement is increasing [1].

The literature on social mediamarketing remains fragmented and is focused on isolated issues, such as tactics for effective communication[58]. In the literature there are several models that describe the ways in which consumers get engaged with companies and the path that a consumer goes through before, during and after the purchase of a product or service. Like the customer journey, the AIDA model and the consumer decision-making process. AIDA stands for Attention, Interest, Desire and Action. The customer journey is a roadmap that shows how a customer get engaged with a company. The roadmap shows which way a customer goes through to buy a product or to gather information [29]. The AIDA model shows what happens when a consumer sees and uses an advertisement [37]. However, during this study, the focus will be on the consumer decision-making process. According to Power and Phillips-Wren [35] new technologies like social media ensure that the decision-making process of individuals, groups and organizations keeps changing. The decision-making process consists of phases that a consumer goes through before, during and after the purchase of a product or service [30]. Social media can have a positive and negative influence on the effectiveness of the decision-making process [35].

The scope of this study will be on the social media platform Facebook. In the Netherlands, Facebook is after WhatsApp the largest social media platform with 10.8 million active users. The age category on Facebook are people between 20-39 years (89\%) [49].

The main research question in this study is: What is the influence of Facebook marketing on the consumer decision-making process?

The remainder of this study is structured as follows. First, a systematic review of the literature is conducted. Followed by an explanation of the research methodology after which the results are analyzed and discussed. The main research question in the conclusion will then be answered followed by a discussion of the implications. The final chapter will discuss the limitations of this research and directions for further research.

\section{Systematic literature review}

In this chapter there will be a review of existing literature in order to solve the research problem. A systematic literature review will be conducted and this systematic literature review will serve as a theoretical framework in the remainder of this research. The systematic literature review ensures that there will be a 
relatively complete picture of the existing literature about the subject [50]. During this systematic literature review, the 'Grounded Theory Literature Review Method' [52] will be used.

In the first instance, the keywords that will be used to answer the research questions are: "social media marketing", "Facebook marketing", "consumer decision-making process", "retail AND social media" and "Facebook AND decision making".

In the second stage the actual search of the keywords takes place. The results of the search can be seen in table 1 below.

Table 1. The actual search of keywords

\begin{tabular}{lll}
\hline Keyword & $\begin{array}{l}\text { Number } \\
\text { of articles }\end{array}$ & Percentage \\
\hline Social media marketing & 704 & $43,03 \%$ \\
Facebook marketing & 32 & $1,96 \%$ \\
$\begin{array}{l}\text { Consumer decision } \\
\text { making process }\end{array}$ & 271 & $16,56 \%$ \\
Retail AND social media & 277 & $16,93 \%$ \\
$\begin{array}{l}\text { Facebook AND decision } \\
\text { making }\end{array}$ & 352 & $21,52 \%$ \\
Total & 1636 & $100 \%$
\end{tabular}

In the third stage, only the relevant articles are selected [52]. This is done based on a number of criteria. First, duplicate items are removed. Then articles were selected based on relevance by looking at the titles and abstracts. These titles and/or abstracts must correspond with the research topic. After this, 107 articles remained. Subsequently, the articles were scanned and another 93 articles fell outside the scope of the research. Ultimately, 14 articles remained that are relevant for the literature review.

In the fourth stage, the articles are analyzed. For each article important findings will be marked that fit within the scope of the review. In the last stage, the marked findings are structured based on the three subquestions that have been formulated [52]. An overview of the remaining 14 articles is given in table 2 .

\subsection{Consumer decision-making process}

There are several authors who describe the decision-making process of consumers [30, 42, 4]. The phases are all very similar, however small differences or extra phases have been added by the authors. In this study it was decided to use the decision-making process as described by Silverman [42] because the phases of this process most clearly represent the total decision-making process of consumers and with the help of these phases it is possible to systematically describe the phase(s) on which Facebook marketing has influence. The decision-making process can be defined as an activity that consists of different phases before, during and after the purchase of a product or service [30]. Silverman [42] describes five phases that a consumer goes through before, during and after the purchase of a product or service. These five phases are problem recognition, info search, evaluation of alternatives, purchase decision and post purchase behavior. Purchase decision reflects the customers desire to purchase a product located on social commerce environments [59].

In a recent study by Miklošík [30] it was reported that the decision-making process includes a number of characteristics/conditions. First, decision-making is a variable process. This means that the process can take a different time per person, from a few minutes to months and years. A consumer can go through all phases or jump directly from the bottom to the top. The process can also be terminated at any time. Second, the decision-making process usually happens unconsciously and the consumer is not aware that the process has started and the process is progressing. The consumer will only realize this when the end product has been purchased or used. Third, the decisionmaking process is strictly individual. It is unique for every consumer and depends on his culture, economic situation, environment and social situation. There is no universal process that applies to all consumers worldwide [32].

Since the arrival of Web 2.0 and social media, the decision-making process has been heavily influenced. Information about products or services is much more accessible and easier to find for consumers. Heinonen [22] describes the relationship between social media and the consumer decision-making process. She states that social media influence the (brand) attitudes and purchase intentions of the consumer. Social media has changed the way people behave during the different stages of the decision-making process.

Only the first two phases of the decision-making process problem recognition and information search and the changes of these phases since the arrival of social media will now be further described. Because the focus of this study is on the first two phases of the decision-making process (see section 2.3 for further explanation).

The decision-making process is described from a rational perspective, besides the rational side of the decision-making process there is also an emotional psychological perspective. However, this study focuses on the rational perspective because the emotional psychological perspective is very complicated and there can be inexplicable reasons why a consumer 
makes a certain choice. The rational perspective makes it less complicated to test and verify hypotheses in the survey.

Problem recognition. Solomon et al[46] explain that the consumer recognizes a problem when there is a difference between the current and the desired situation, which must be sufficiently large to activate the decision-making process. Yadav et al.[54] claim that problem recognition can occur due to internal signals (e.g. hunger). However, problem recognition can also occur when a consumer is stimulated by external factors, for example advertising on social media channels [24].

Constantinides and Fountain[10] argue that external factors like social media provide external incentives in the decision-making process. As a result, social media channels ensure that consumer creates new needs. By creating these new needs, the consumer recognizes a problem and wants to solve this problem. This can be done in making a purchase. The type of need influences the progress of the decision-making process. A primary need will progress faster and smoother than a secondary or tertiary need [30].

Information search. After the consumer has recognized a problem, one looks for information about the purchase. In this phase, comparing products, finding information about these products and judging the best option play an important role [42]. Consumers can search information in two different ways, internally and externally. Internal search means that the consumer has knowledge through previous experience with the product or service. External search means that the consumer collects information from the internet or acquaintances [41]. Sahelices-Pinto et al. [41] claim that the search for information can be passive or active, meaning that consumers sometimes receive information passively, while at other times they actively search for information by, for example, searching information on the internet or visiting stores.

According to Miklošík [30] the second phase of the decision-making process has been shortened by social media. Consumers search online for information about their purchase. Because a lot of online information is available, consumers find sooner information that they need [30]. Here they gathered in-depth knowledge about a product. Smith and Chaffey [45] asserts that social media is one of the main reasons why consumers buy their products online. Because consumers receive information about a product or service on chats, via videos on YouTube, emails and messages on Facebook and Twitter, they are more likely to purchase a product online.

\subsection{Social media and Facebook marketing}

Weinberg [51] asserts that social media marketing is a process whereby retailers are encouraged to promote or offer their product or service through social media channels and to communicate with customers. Öztamur and Karakadılar [33] support this and claim that social media marketing is a mechanism to create more website visits by generating interest among consumers via social media channels. Additionally, it is crucial that marketers know the needs of their consumers. This is important because it enables marketers to communicate with consumers in a personal way [57]. Mas-Tur et al[28] contend that the biggest advantage of social media marketing for retailers is that they can collect significant amounts of information about customers. This information can be used in various ways, for example in the development of new products, feedback and selection of segments.

An important aspect of social media marketing is content. Content must be relevant, fit within the corporate culture, business goals and deliver customer value [15]. Social media content can be used in advertisements to influence consumer behavior. Moreover, content that consumers attracts is more likely to be shared with their own network. High quality content is therefore essential and can encourage consumers to engage [2].

This study focuses on the social media platform Facebook and therefore there will be now a further explanation about the phenomenon Facebook marketing. Facebook is a social media platform that allows people to communicate with friends, family and acquaintances, share photos and chat. Additionally, it has grown as an important platform for social media marketing [23]. The time spend on Facebook is more than on sites like Google, Yahoo, YouTube, Wikipedia and other social media platforms [48]. For marketeers this is an important reason to be active on Facebook. Facebook users are more likely to view a product or download a discount code when it is on Facebook [48]. Moreover, Facebook enables marketers to enter into a two-way relationship with consumers and can accelerate the sharing of information about a brand and thus foster the performance of a brand [18]. According to Marsden (2011) Facebook serves mainly as a supporting platform between the retailer and the customer during the sales process. Facebook marketing can be used for different purposes, namely forcing the customer to purchase, creating customer trust for a future purchase and customer promotion using wordof-mouth advertising [27]. 


\subsection{Influence of Facebook marketing on decision-making}

There are several ways to influence the decision-making process of consumers by Facebook marketing. Facebook has itself developed a number of tools for marketers who make it easier to approach consumers like Facebook ads manager where consumers can be triggered based on various marketing objectives like (brand) awareness, consideration and conversion [21]. Moreover, Facebook users can also 'like' pages, post reviews on business pages, make recommendations and share pages or products.

2.3.1. Facebook advertisements. Personal targeting of Facebook users with offers is seen as a big advantage for retailers [21]. Yang et al [56] underline this benefit and emphasize that the biggest advantage of Facebook marketing is the ability to directly target potential customers. This means that potential customers see personalized advertisements on Facebook that are based on demographic data, interests and behavior. When consumers use mobile phones, Facebook can locate consumers through the global positioning system (GPS) [3]. For example, it is possible to target a particular location where Facebook users have recently been. The mobile use of Facebook is very high, 1.66 billion people use a mobile when they are active on Facebook. That is more than 90 percent of monthly active users [36].

Carter [7] pretends that Facebook is a powerful targeting channel. With Facebook targeting, just as many people can be reached as with traditional marketing, but at a lower price. Retailers can determine exactly when and how long their targeting campaigns should run [7]. Previous studies by Kumar and Raju [25] and Roa and Rao [39] have shown that advertising in general has a positive impact on the decisionmaking process. Additionally, as mentioned in the consumer decision-making process part, the consumer can recognize a problem by external factors like advertisements [24].

Therefore:

H1: Facebook advertisements have a positive influence on problem recognition

2.3.2. Recommending and sharing. In the post purchase evaluation phase, the consumer will firstly be inclined to share his purchase via social media channels. Miklošík [30] affirms that consumers are looking for appreciation and advice from other users to increase the added value of their purchase. By sharing a positive experience on Facebook or by recommending the purchased product, friends of this user can create a need and get also the feeling of wanting the product. Besides, if a consumer shares a link to a specific product or discount on Facebook, it appears in the news feed of friends of the consumer. Friends of the user can comment on this or share the link with their friends [38].

Therefore, the second hypothesis is:

$\mathrm{H} 2$ : Recommending or sharing pages, products or discounts by Facebook friends has a positive influence on problem recognition

2.3.3. Likes and reviews. First, there are the Facebook pages of retailers themselves. Smith and Treadway [44] affirm that these business pages have become the favorite channel for retailers to communicate with customers and to inform them. Retailers can display their products by taking photos, videos, opinion polls, placing promotional codes and organizing events. Another important characteristic of a business page is that customers can communicate with the company [20]. Think of giving an opinion about a (new) product, discussing with other customers and asking questions to employees of the company. If the consumer is a fan of a brand, one can 'like' the company page. When the consumer has 'liked' the page, one receives updates about that page in his news feed. In addition, one can see activities of other users who have also liked the page in his newsfeed [31]. Harris and Dennis [21] maintain that the most popular reasons among consumers to like a certain company were getting discounts and showing to their friends which brands they support. When consumers search for information in the second phase of the decision-making process, they can look at the number of Facebook friends who have liked a certain brand on Facebook. Since trust is an important factor when making a purchase [21].

Therefore, the third hypothesis is:

H3: The number of Facebook friends who have liked a page of interest of the consumer positively influences the search of information

Another important role that a company page plays is that consumers can share their experiences with the product. As mentioned earlier two-thirds of the consumer activities in the pre-purchase phases are concerned with reading reviews on the internet and word-of-mouth recommendations from family and friends [13]. Research by Nielsen [48] showed that consumers most trust their friends and family for a review of a product or service. They also trust reviews from other consumers on a Facebook company page more than information on the company's website.

Therefore:

H4: Reading reviews of friends or other users on Facebook positively influences the search of information 
To clarify the hypotheses in combination with the consumer decision-making process, see the conceptual model (figure 1). Based on the last column of table 2 and the theory used in this section, the Facebook marketing activities and hypotheses are linked to a certain phase in the decision-making process. A study by Richard and Guppy [38] used the same conceptual model for their research. However, their research focused on the influence of Facebook marketing activities on consumer purchase intention and this research focuses on the first two phases of the consumer decision-making process.

In this conceptual model, the first two phases of the decision-making process have been combined into the Facebook Marketing Intelligence component. Herbert Simon [43] describes the first two phases of the decision-making process; problem recognition and searching for information together as intelligence. Intelligence relates to the identification of the problem and information that needs to be collected concerning the problem [43]. So, the Facebook Marketing Intelligence component means that when consumers create a need, they identify a problem and search for information to solve it.

To give an overview of the articles used during the literature review combined with the topic of these articles, see table 2. A + means that the topic; decisionmaking and/or Facebook marketing is included in that article and a - means that the topic is not included in the article.

Table 2. Overview of used articles by topic

\begin{tabular}{|c|c|c|}
\hline Keyword & $\begin{array}{l}\text { Decision- } \\
\text { making }\end{array}$ & $\begin{array}{c}\text { Facebook } \\
\text { marketing }\end{array}$ \\
\hline $\begin{array}{l}\text { Andrej Miklošík } \\
(2015)[30]\end{array}$ & + & - \\
\hline Heinonen (2011)[22] & + & - \\
\hline $\begin{array}{l}\text { Constantinides and } \\
\text { Fountain (2008)[10] }\end{array}$ & + & - \\
\hline $\begin{array}{l}\text { Sahelices-Pinto et al. } \\
(2018)[41]\end{array}$ & + & - \\
\hline $\begin{array}{l}\text { Power and Phillips-Wren } \\
\text { (2011)[35] }\end{array}$ & + & - \\
\hline $\begin{array}{l}\text { Öztamur and Karakadilar } \\
(2014)[33]\end{array}$ & - & + \\
\hline Mas-Tur et al. (2016)[28] & - & + \\
\hline $\begin{array}{l}\text { Ashley and Tuten } \\
(2015)[2]\end{array}$ & - & + \\
\hline $\begin{array}{l}\text { Harris and Dennis } \\
(2011)[21]\end{array}$ & - & + \\
\hline Yadav et al. (2013)[54] & + & + \\
\hline $\begin{array}{l}\text { Kumar and Raju } \\
(2013)[25]\end{array}$ & + & + \\
\hline
\end{tabular}

Roa and Roa (2012)[39]

Richard and Guppy (2014)[38]

Nelson-Field et al. (2012)[31]

\section{Methodology}

The hypotheses are developed based on how retailers try to influence consumers (e.g. advertisements) in the first two phases of the decisionmaking process. So, for certain phases of the decisionmaking process, questions will be formulated to measure the effect of Facebook marketing in that particular phase.

\subsection{Data collection}

The study was conducted in the Netherlands and the target group of this research were students at the University of Twente who are active on Facebook. The aim of the survey was to obtain the largest possible number of respondents. Because a large sample size will increase the reliability of the research[14]. To calculate the sample size, the Yamane [55] formula was used. The Yamane [55] formula is a simplified formula for calculating the sample size.

The formula is: $\mathrm{n}=\mathrm{N} /(1+\mathrm{N}$ (e) 2$)$

$\mathrm{n}=152 /\left(1+152(0,05)^{\wedge} 2\right)=110,14=110$ respondents

Note: $n$ is the sample size, $N$ is the total population of the group students, and $e$ is the desired level of precision (confidence level).

In order to collect the minimum number of respondents of 110, a gift card was awarded among the respondents. The respondents were approached by an email. An online survey has been chosen because it provides a faster and higher response and the design is more attractive [6].

\subsection{Survey}

The survey was structured in three parts. Firstly, by asking general questions like the average number of hours of use of Facebook, on what kind of device the respondent is active on Facebook and whether the respondent has ever made an impulsive purchase after seeing an advertisement on Facebook. Demographic questions like gender and age were also asked. These questions were used as control variables in the analysis. The general questions were followed by questions to test the four hypotheses. These questions 
were about the Facebook marketing activities [21,54,25,38,39]:

- Advertisements;

- Recommendations/sharing;

- Likes and

- Reviews.

Due to limited space we cannot add the full questionnaire in the appendix but we can send it upon request.

\section{Results}

In this chapter the data from the surveys has been analyzed. A total of 121 students started the survey. Due to incomplete answers, 9 surveys were excluded, so 112 surveys remained.

\subsection{Descriptive statistics}

The first questions in the survey focused on gathering information about gender, age, Facebook respondents [14]. So, as mentioned in the methodology chapter 110 respondents were necessary to collect with at a confidence level of $95 \%$. After two weeks this number was accomplished and eventually 112 students completed the entire survey. Concerning the generalizability, the target group of this study were students at the University of Twente. The age category that is most on Facebook in the Netherlands are people between 20-39 years (89\%) (van der Veer, Boekee, Hoekstra, \& Peters, 2018). Thus, this statistic indicated that the age of the respondents in the survey were equal to the age of the largest number of Facebook users in the Netherlands.

Cooper and Schindler [12] contend that reliability is the overall consistency of a measure. Cronbach's alpha $(\alpha)$ is the measurement to test the consistency. The test is acceptable when $\alpha>.70$ (Nunnally \& Bernstein, 1994). A confirmatory factor analysis was performed to assess the validity. To check if the test shows acceptable convergent validity, the factor

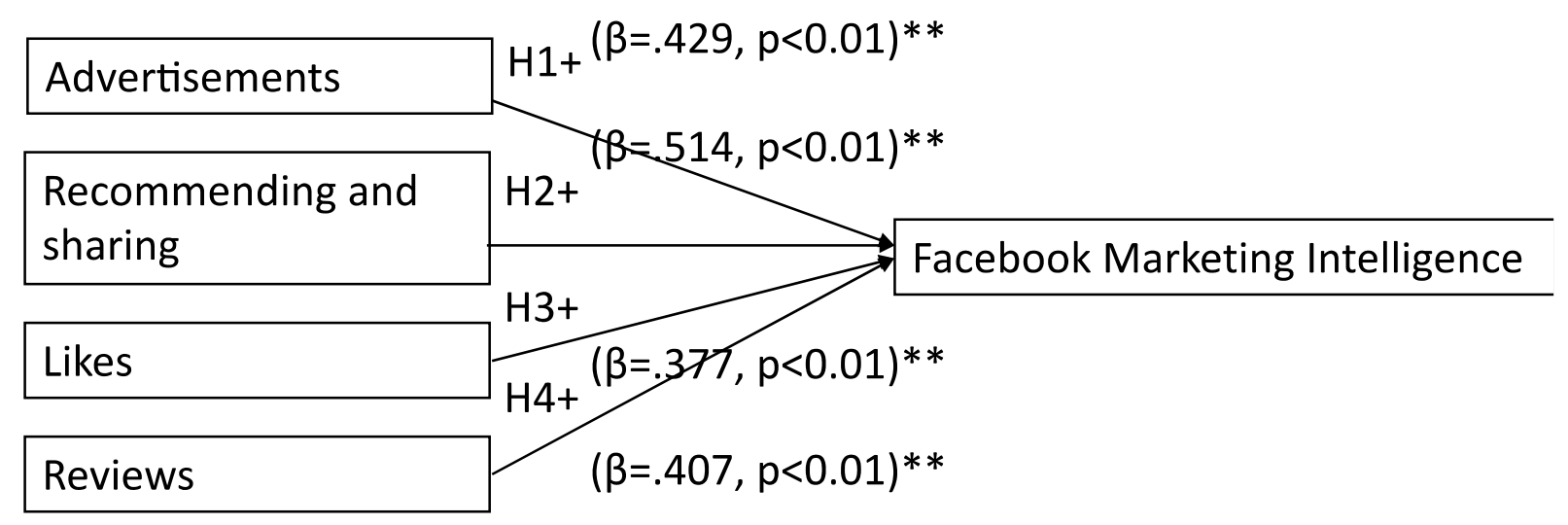

Figure 1. Conceptual model with results

usage, the type of device on which the respondent was most active on Facebook and whether the respondent has ever made an impulsive purchase after seeing an advertisement on Facebook. The remaining 112 respondents consisted of 58 women $(51.8 \%)$ and 54 men $(48.2 \%)$. The most respondents came from the age category between 22 and 25 years old $(64,3 \%)$. The average hours of Facebook use per week is very different among respondents. The largest percentage is on average 1 to 3 hours per week on Facebook (35.7\%). The most commonly used device to be active on Facebook is the mobile phone $(74.1 \%)$. Finally, the vast majority of respondents indicated that they never made an impulsive purchase after seeing an advertisement on Facebook (64.3\%).

\subsection{Reliability and validity}

To increase the reliability of the research the aim of the survey was to obtain the largest possible number of loadings of each item must be above .70 [19]. Each scale item showed acceptable reliability $(\alpha>$.70) and convergent validity (factor loadings $>.70)$. The study is therefore reliable and valid and can be used for further investigation. The explained variance of advertisements, recommend/share, likes and reviews were $77,4 \%, 82,3 \%, 81,1 \%$ and $91,6 \%$. These results show that Facebook marketing has an important impact on the first two phases of consumer decision-making process.

\subsection{Hypothesis testing}

To test the hypotheses, a multiple regression analysis was conducted. The confirmatory factor

analysis was not only used to measure validity, but also to measure the correlation between the different statements. As expected, four different items were extracted from the factor analysis. The four items were computed into four new variables, namely 
advertisements, recommend/share, likes and reviews. Subsequently, by means of multiple regression analysis it was tested whether these independent variables affected the dependent variables problem recognition and information search. The results are shown in table 3 below.

Table 3. Multiple regression analysis results $\left({ }^{*} p<0.05,{ }^{* *} p<0.01\right)$

\begin{tabular}{lcccc}
\hline Hypothesis & $\begin{array}{c}\mathbf{R} \\
\text { square }\end{array}$ & $\begin{array}{c}\text { Beta } \\
\boldsymbol{\beta}\end{array}$ & $\begin{array}{c}\boldsymbol{t} \text { - } \\
\text { statistic }\end{array}$ & $\boldsymbol{p}$-value \\
\hline $\mathrm{H} 1$ & \multirow{2}{*}{0.676} & 0.429 & 6.754 & $\mathrm{p}<0.01^{* *}$ \\
$\mathrm{H} 2$ & & 0.514 & 8.085 & $\mathrm{p}<0.01^{* *}$ \\
$\mathrm{H} 3$ & & 0.377 & 4.485 & $\mathrm{p}<0.01^{* *}$ \\
$\mathrm{H} 4$ & 0.483 & 0.407 & 4.853 & $\mathrm{p}<0.01^{* *}$
\end{tabular}

Advertisements and recommend/share had a combined $\mathrm{R}$ square of 0.676 . This means that $67.6 \%$ of the variation in problem recognition can be explained by the independent variables advertisements and recommend/share. Likes and reviews had a combined $\mathrm{R}$ square of 0.483 . So, $48,3 \%$ of the variation in information search can be explained by the independent variables likes and reviews. According to the results from the multiple regression analysis, all hypotheses were supported and had a significant positive influence on the first two phases of the decision-making process; problem recognition and information search. Figure 1 shows the conceptual model from the literature review again, including all beta and p-values.

Recommending and sharing pages, products or discounts $(\beta=0.514)$ had a greater effect on problem recognition than Facebook advertisements $(\beta=0.429)$. In addition, reviews $(\beta=0.407)$ had a greater effect on information search than likes $(\beta=0.377)$. Moreover, it has been tested whether the first phase of the decisionmaking process problem recognition has a positive influence on the second phase of the decision-making process search of information. It was found that problem recognition had a significant positive influence on search of information $(\beta=0.400, p<.001)$.

It was also examined whether having ever made an impulsive purchase after seeing a Facebook advertisement affects the extent to which a respondent is influenced by Facebook marketing. An independent samples T-test was conducted to test if there was statistical evidence between making an impulsive purchase after seeing a Facebook advertisement and being influenced by the Facebook marketing activities advertisements, recommend/share, likes and reviews. So, it is tested whether respondents who have ever made an impulsive purchase are on average more likely to be influenced by Facebook marketing than respondents who have never made an impulsive purchase before.

The independent samples T-test showed that there was statistical evidence that respondents who have ever made an impulsive purchase after seeing a Facebook advertisement were on average more likely to be affected by Facebook marketing activities than respondents who did not make an impulsive purchase, see table 4 .

Table 4. Independent samples T-test results impulsive purchases $\left({ }^{*} p<0.05,{ }^{* *} p<0.01\right)$

\begin{tabular}{lcc}
\hline $\begin{array}{l}\text { Facebook } \\
\text { marketing } \\
\text { activities }\end{array}$ & t-statistic & p-value \\
\hline Advertisements & $\mathrm{t}(104)=5.171$ & $\mathrm{p}=0.000^{* *}$ \\
Recommend/share & $\mathrm{t}(110)=2.985$ & $\mathrm{p}=0.002^{* *}$ \\
Likes & $\mathrm{t}(105)=1.953$ & $\mathrm{p}=0.027^{*}$ \\
Reviews & $\mathrm{t}(99)=2.073$ & $\mathrm{p}=0.041^{*}$
\end{tabular}

The results of comparing the means show that respondents who once made an impulsive purchase after seeing a Facebook advertisement are the most influenced by reviews $(M=3,91 ; S D=0,77)$, followed by advertisements $(M=3,78 ; S D=0,73)$, likes $(M=3,66$; $S D=0,72)$ and recommend/share $(M=3,59 ; S D=0,87)$. Besides, they are more likely to recognize a need and search for information on Facebook. However, this is a logical outcome, since the hypothesis testing showed that Facebook marketing had a positive influence on the first two phases of the decision-making process.

Moreover, it has been examined whether the control variables; age, gender, average number of hours of use of Facebook per week and on which device the respondent is most active on Facebook caused differences in the degree of influence of Facebook marketing activities. However, no significant differences were discovered and therefore these variables are not considered.

\section{Discussion}

The systematic literature review led to the expectation that four Facebook marketing activities affect the first two phases of the decision-making process. Four hypotheses were used to check whether this expectation was correct.

The first hypothesis was to test whether Facebook advertisements had a positive influence on problem recognition. Based on results from the multiple regression analysis, this study found a positive significant influence between Facebook advertisements and problem recognition. So, the first hypothesis has been supported and was consistent with previous studies where advertisements had a positive influence 
on decision-making [25, 39]. However, these studies tested the influence of advertising in general on the decision-making process. The added value of this research is that advertisements specifically on Facebook had a positive influence on the decisionmaking process.

The second hypothesis was about whether recommending and sharing pages, products and discounts has a positive influence on problem recognition. This hypothesis was also supported and there was a positive significant influence between recommending/sharing and problem recognition. This research showed that recommending/sharing had more impact on problem recognition than Facebook advertisements. This was supported by a study of Harris and Dennis [21] who claim that people trust their family and friends more than any other type of information about products and services.

The third and fourth hypotheses were used to test whether likes of Facebook friends and reviews affected the second phase of the decision-making process; the search of information. Likes from Facebook friends and reviews had a positive significant impact on the search of information phase. Trust in a certain brand is an important factor when searching for information [21]. Because of this, $65 \%$ of the respondents from this study trust a brand that was liked by friends more. The positive significant impact of reviews on search of information was consistent [48] that concluded that consumers have more confidence in reviews from family, friend and other consumers than information from a company itself. So, Facebook marketing activities affect as expected the first two phases of the decision-making process.

Furthermore, the results showed that there was statistical evidence that respondents who have ever made an impulsive purchase after seeing a Facebook advertisement were on average more affected by Facebook marketing activities than respondents who have never made an impulsive purchase. The Facebook marketing activity that on average affects the respondents who have ever made an impulsive purchase the most were reviews. This was in line with previous studies that indicate that the awareness effect of reviews encourages people to buy products they would not normally have noticed $[26,53]$. The added value of this study is that it concerns impulsive purchases after seeing a Facebook advertisement. The two studies of Lo et al. [26] and Xiang et al. [53] did research on making impulsive purchases after seeing reviews in general. This study found that of all Facebook marketing activities, reviews had the most effect on consumers who have ever made an impulsive purchase.

\section{Conclusion}

The objectives of this study were to discover to what extent Facebook marketing had an influence on the consumer decision-making process and to explore the impact of Facebook. So, the first objective was to discover to what extent Facebook marketing had an influence on the consumer decision-making process. The Facebook marketing activities advertisements and recommend/share had a positive influence on the first stage of decision-making; problem recognition. This means that when retailers approach consumers on Facebook through advertisements, consumers are more likely to recognize a 'problem' and thus create a need. The same applies to the recommending and sharing of pages, products and discounts. When retailers encourage consumers to recommend or share a page, product or discount, other consumers are more likely to recognize a 'problem' and create a need.

The Facebook marketing activities likes and reviews had a positive influence on the second stage of decision-making; search of information. This means that when retailers have many likes and positive reviews on their Facebook page, consumers have more trust in their company and are more likely to buy their product/service there.

However, not all four Facebook marketing activities had an equal influence on consumer decisionmaking. This research showed that recommending and sharing pages, products and discounts had the most influence on the decision-making process. Followed by Facebook advertisements, reviews and likes. It can also be concluded that that the influence of Facebook marketing was higher for consumers who have ever made an impulsive purchase after seeing a Facebook advertisement than consumers who have never made an impulsive purchase.

\section{Limitations}

This study contains some limitations:

This study has only examined the influence of Facebook marketing activities on Facebook Marketing Intelligence. It would be beneficial to test the relationship between Facebook Marketing Intelligence and the intention to purchase phase.

Thirdly, $64.3 \%$ of the respondents were between 22 and 25 years old, which limits the generalizability of the research. 


\section{References}

[1] Araujo, T., Neijens, P., \& Vliegenhart, R. (2015). What motivates consumers to re-tweet brand content? The impact of information, emotion and traceability on pass-along behavior. Journal of Advertising Research, Vol. 55(3), 284-295.

[2] Ashley, C., \& Tuten, T. (2015). Creative Strategies in Social Media Marketing: An Exploratory Study of Branded Social Content and Consumer Engagement. Psychology \& Marketing, Vol. 32(1), 15-27.

[3] Bayer, J., Ellison, N., Schoenebeck, S., Brady, E., \& Falk, E. B. (2016). Facebook in context(s): Measuring emotional responses across time and space. New Media and Society, Vol. 20(3), 1047-1067.

[4] Blackwell, R. D., Miniard, P. W., \& Engel, J. F. (2006). Consumer Behavior. Mason, Ohio: Thomson Higher Education.

[5] Bourne, F. S. (1957). Group Influence in Marketing and Public Relations. Paris: Unesco.

[6] Bryman, A., \& Bell, E. (2011). Business Research Methods. New York: Oxford University Press.

[7] Carter, B. (2011). The Like Economy: How Businesses Make Money With Facebook. USA: Que Publishing.

[8] Chokkattu, J. (2018, 5 3). The top trends we saw at Mobile World Congress 2018. Retrieved from Digital https://www.digitaltrends.com/mobile/mobileworld-congress-smartphone-trends-2018/

[9] Constantinides, E. (2009). Social Media / Web 2.0 as Marketing Parameter: An Introduction. Proceedings of 8th international congress marketing trends, 15-17.

[10] Constantinides, E., \& Fountain, S. J. (2008). Web 2.0: Conceptual foundation and marketing issues. Journal of Direct, Data and Digital Marketing Practice, 231-244.

[11] Constantinides, E., Lorenzo Romero, C., \& Gómez Boria, M. (2008). Social Media: A New Frontier for Retailers? European Retail Research, 1-28.

[12] Cooper, D., \& Schindler, P. (2014). Busines Research Methods. New York: McGraw Hill.

[13] Court, D., Elzinga, D., Mulder, S., \& Vetvik, O. J. (2009). The consumer decision journey. McKinsey Quarterly.

[14] Creswell, J. W., \& Plano Clark, V. L. (2011). Designing and Conducting Mixed Methods Research. Thousand Oaks, California: SAGE Publications, Inc.

[15] Effing, R., Spil, T., Both, M., \& Ogbuji, B. (2018). Digital Future. Enschede: Social Power.

[16] Facebook. (2018). Ads Manager. Retrieved from Facebook Ads Manager: https://www.facebook.com/adsmanager/creation
[17] Fenner, R. (2018, 8 14). ANALYSIS: How the global smartphone market is slowing down? Retrieved from IOL: https://www.iol.co.za/businessreport/international/analysis-how-the-globalsmartphone-market-is-slowing-down-16528757

[18] Fulgoni, G. M. (2016). In the Digital World, Not Everything That Can Be Measured Matters. Journal of Advertising Research, Vol. 56(1), 2-9.

[19] Hair Jr, J. F., Black, W. C., Babin, B. J., \& Anderson, R. E. (2010). Mutilvariate data analysis: A global perspective. Upper Saddle River, NJ: Pearson Prentice Hall.

[20] Hardwick, J., Delarue, L., Ardley, B., \& Taylor, N. (2011). Mobile phones purchases and consumer decision making process: the role of Facebook online advertising. Lincoln: Lincoln Business School.

[21] Harris, L., \& Dennis, C. (2011). Engaging customers on Facebook: Challenges for e-retailers. Journal of Consumer Behavior, Vol. 10(6), 338-346.

[22] Heinonen, K. (2011). Consumer activity in social media: Managerial approaches to consumers' social media behavior. Journal of Consumer Behaviour, Vol. 10(6), 356-364.

[23] Holzner, S. (2009). Facebook marketing: leverage social media to grow your business. Indianapolis: Que Publishing.

[24] Kotler, P., \& Keller, K. L. (2009). Marketing management. Upper Saddle River, New Jersey: Pearson Prentice Hall.

[25] Kumar, D., \& Raju, K. (2013). The Role of Advertising in Consumer Decision Making. Journal of Business and Management, vol. 14(3), 37-45.

[26] Lo, L.-S., Lin, S.-W., \& Hsu, L.-Y. (2016). Motivation for online impulse buying: A two-factor theory perspective. International Journal of Information Management, Vol. 36(5), 759-772.

[27] Marsden, P. (2011, 4 18). F-commerce helps you facilitate and execute sales transactions using Facebook. Retrieved from Digital Intelligence Today: https://digitalintelligencetoday.com/fcommerce-faq-all-you-ever-wanted-to-knowabout-facebook-commerce-but-were-afraid-to-ask/

[28] Mas-Tur, A., Tur-Porcar, A., \& Llorca, A. (2016). Social Media Marketing For Adolescents. Psychology \& Marketing, 33(12), 1119-1125.

[29] McKnight, C. (2017). Customer Journey Maps: A Path to Innovation and Increased Profits. EContent, Vol. 40(6), 20-21.

[30] Miklošík, A. (2015). Changes in purchasing decisionmaking process of consumers in the digital era. European Journal of Science and Theology, Vol. 11(6), 167-176.

[31] Nelson-Field, K., Riebe, E., \& Sharp, B. (2012). What's not to "like?" Can a Facebook fan base give a 
brand the advertising reach it needs? Journal of Advertising Research, Vol. 52(2), 262-269.

[32] Nunnally, J., \& Bernstein, L. (1994). Psychometric theory. New York: McGraw-Hill Higher, INC.

[33] Oztamur, D., \& Karakadilar, I. S. (2014). Exploring the role of social media for SMEs: as a new marketing strategy tool for the firm performance perspective. Procedia - Social and Behavioral Sciences, Volume $150,511-520$.

[34] Parsons, A. L., \& Lepkowska-White, E. (2018). Social Media Marketing Management: A Conceptual Framework. Journal of Internet Commerce, Vol. 17(2), 81-95.

[35] Power, D. J., \& Phillips-Wren, G. (2011). Impact of Social Media and Web 2.0 on Decision-Making. Journal of Decision Systems, Vol. 20(3), 249-26.

[36] Querne, S. (2018). How consumer behaviour is changing the face of retail. Utrecht: Shopping today.

[37] Rawal, P. (2013). AIDA Marketing Communication Model: Stimulating a purchase decision in the minds of the consumers through a linear progression of steps. Irc's International Journal of Multidisciplinary Research in Social \& Management Sciences, Vol. 1(1), 37-44.

[38] Richard, J. E., \& Guppy, S. (2014). Facebook: Investigating the influence on consumer purchase intention. Asian Journal of Business Research, vol. $4(2)$.

[39] Roa, K., \& Rao, U. (2012). Impact of advertisements on consumer decision making process. PRIMA: Practices and Research in Marketing, vol. 3(1), 1527.

[40] Rutishauser, G. E., Rickert, S., \& Sänger, F. (2015, 6). A perfect storm brewing in the global beer business. RetrievedfromMcKinsey:https://www.mckinsey.co $\mathrm{m} /$ businessunctions/marketing-and sales/ournsights/a-perfect-storm-brewing-in-theglobal-beer-business

[41] Sahelices-Pinto, C., Lanero-Carrizo, A., \& VázquezBurguete, J. (2018). Social commitment or selfinterest? Effect of responsible practices performance motivations of firms on the consumer decision-making process. Journal of Marketing Communications, Vol. 24(3), 304-319.

[42] Silverman, G. (2011). The Secrets of Word-of-Mouth Marketing. New York: AMACOM.

[43] Simon, H. A. (1960). The New Science of Management Decision. New York: Harper.

[44] Smith, M., \& Treadway, C. (2010). Facebook marketing an hour a day. Indianapolis: Wiley Publishing.

[45] Smith, P., \& Chaffey, D. (2012). Emarketing Excellence. Abingdon: Taylor \& Francis Ltd.
[46] Solomon, M., Bamossy, G., \& Askegaard, S. (2002). Consumer Behavior: A European Perspective. Upper Saddle River, N.J: Pearson Prentice Hall.

[47] Sternthal, B., \& Craig, C. (1982). Consumer Behavior: An Information Processing Perspective. Englewood Cliffs, N.J: Prentice Hall.

[48] The Nielsen Company. (2014). The role of content in the consumer decision making process. New York: The Nielsen Company.

[49] van der Veer, N., Boekee, S., Hoekstra, H., \& Peters, O. (2018). Social media onderzoek 2018. Amsterdam: Newcom.

[50] Webster, J., \& Watson, R. T. (2002). Analyzing the past to prepare for the future: writing a literature review. MIS Quarterly, Vol. 26(2), xiii-xxiii.

[51] Weinberg, T. (2009). The New Community Rules: Marketing on the Social Web. Sebastopol: O'Reilly Media Inc.

[52] Wolfswinkel, J. F., Furtmueller, E., \& Wilderom, C. P. (2013). Using grounded theory as a method for rigorously reviewing literature. European Journal of Information Systems, Vol. 22(1), 45-55.

[53] Xiang, L., Zheng, X., Lee, M. K., \& Zhao, D. (2016). Exploring consumers' impulse buying behavior on social commerce platform: The role of parasocial interaction. International Journal of Information Management, Vol 36(3), 333-347.

[54] Yadav, M. S., de Valck, K., Hennig-Thurau, T., Hoffman, D. L., \& Spann, M. (2013). Social Commerce: A Contingency Framework for Assessing Marketing Potential. Journal of Interactive Marketing, Vol. 27, 311-323.

[55] Yamane, T. (1967). Statistics, An Introductory Analysis. New York: Harper and Row.

[56] Yang, T., Kim, D., \& Dhalwani, V. (2008). Social networking as a new trend in e-marketing. Boston: Springer.

[57] Zhu, Y.-Q., \& Chen, H.-G. (2015). Social media and human need satisfaction: Implications for social media marketing. Business Horizons, Vol. 58(3), 335-345.

[58] Felix, R, Rauschnabelb,P A, Hinsch, C (2017). Elements of strategic social media marketing: A holistic framework, Business Research, 70, 118-126.

[59] Mikalef, P, Pappas, IO \& Gianakkas, MN(2017). Value co-creation and purchase intention in social commerce: The enabling role of word-of-mouth and trust. AMCIS Boston. 